Jurnal Keperawatan Silampari

Volume 4, Nomor 2, Juni 2021

e-ISSN: 2581-1975

p-ISSN: 2597-7482

DOI: https://doi.org/10.31539/jks.v4i2.1995

\title{
KEPATUHAN PERAWAT DALAM MELAKUKAN ORAL HYGIENE DI UNIT PERAWATAN INTENSIF
}

\author{
Musdalipah $^{1}$, Yuliana Syam ${ }^{2}$, Takdir Tahir ${ }^{3}$ \\ Universitas Hasanuddin ${ }^{1,2,3}$ \\ iphamahmud@gmail.com ${ }^{1}$
}

\begin{abstract}
ABSTRAK
Penelitian ini bertujuan untuk mengidentifikasi faktor yang mempengaruhi kepatuhan perawat dan menemukan solusi terbaik untuk meningkatkan kepatuhan dalam melaksanakan oral hygiene. Metode penelitian dimulai dengan pencarian artikel ilmiah di 4 database yaitu pubmed, wiley, science direct, dan google scholar. Hasil penelitian dari 7 artikel yang diinklusi, 42,85\% (3 artikel) menyatakan pengetahuan dan persepsi perawat adalah faktor utama yang mempengaruhi kepatuhan perawat, dan 14,3\% (1 artikel) yang menyatakan praktik/fasilitas pelayanan berpengaruh terhadap kepatuhan. Ditemukan faktor lain diantaranya; keterbatasan waktu, motivasi, beban kerja perawat, tidak tersedianya prosedur oral hygiene dan kurangnya kolaborasi interprofesional, sehingga solusi terbaik adalah meningkatkan pengetahuan dan kompetensi perawat dengan pelatihan, lokakarya maupun sistem pemantauan dalam pelaksanaan bundle VAP. Simpulan, pengetahuan dan persepsi perawat adalah faktor utama yang mempengaruhi kepatuhan perawat dalam melakukan oral hygiene, sehingga meningkatkan pengetahuan dan kompetensi merupakan solusi terbaik sebagai upaya bersama dalam menurunkan insiden VAP.
\end{abstract}

Kata kunci: Bundle VAP, Compliance, Intensive Care Unit, Oral Hygiene

\begin{abstract}
ABSTRAK
This study aims to identify factors that influence nurse compliance and find the best solution to improve adherence to oral hygiene. The research method begins with searching scientific articles in 4 databases, namely PubMed, Wiley, science direct, and google scholar. The results of the study of 7 included articles, $42.85 \%$ (3 pieces) stated that nurses' knowledge and perceptions were the main factors that influenced nurse compliance, and $14.3 \%$ (1 article) indicated that service practices/facilities affected adherence. Other factors were found including; limited time, motivation, nurse workload, unavailability of oral hygiene procedures, and lack of interprofessional collaboration, so the best solution is to increase the knowledge and competence of nurses with training, workshops, and monitoring systems in the implementation of the $V A P$ bundle. In conclusion, nurses' knowledge and perceptions are the main factors that affect nurse compliance in performing oral hygiene, so increasing knowledge and competence is the best solution as a joint effort to reduce the incidence of VAP.
\end{abstract}

Keywords: VAP Bundle, Compliance, Intensive Care Unit, Oral Hygiene 


\section{PENDAHULUAN}

Perawat sebagai pemberi layanan utama, memegang peranan yang sangat penting dalam menurunkan kejadian ventilator associated pneumonia, upaya untuk menurunkan kejadian VAP, perawat yang telah mendapat pelatihan tentang strategi pencegahan VAP diantaranya oral hygiene mengalami tingkat kepatuhan yang lebih tinggi dibandingkan yang tidak mendapat pelatihan sebelumnya (Aloush, 2017).

Salah satu masalah yang umum terjadi pada pasien dengan ventilasi mekanik adalah kejadian Ventilator Associated Pneumonia (VAP), hal tersebut menjadi masalah utama di unit perawatan intensif. Insiden VAP berkisar $10 \%$ di negara berkembang dan 7\% dari kejadian infeksi di negara maju (Khan et al., 2017).

Menurut laporan Infections Disease Society of America (IDSA) dan American Thorasic Society (ATS) kematian VAP di USA mencapai 13\% (Kalil et al., 2016). Insiden VAP dari 20 provinsi di China daratan dari tahun 2006-2014 adalah 23,8\% angka yang masih terbilang tinggi dari standar CDC 5,8\% (INICC, 2016), sehingga diperlukan konsistensi dalam melakukan pencegahan terkait kejadian VAP.

Strategi pencegahan yang direkomendasikan dari IHI yang dikenal dengan bundle VAP, telah terbukti efektif dalam menurunkan insiden VAP jika dilakukan secara konsisten dan simultan (Bassi et al., 2017). Bundle VAP ini merupakan kumpulan intervensi berdasarkan evidence base practice yang meliputi tindakan mencegah kolonisasi bakteri diantaranya kepatuhan mencuci tangan, menggunakan sarung tangan, melakukan perawatan mulut/oral hygiene, profilaksis untuk pencernaan, mengganti sirkuit ventilator, sedangkan tindakan pencegahan aspirasi yaitu head of bed $>30-45^{\circ}$, meminimalisir sedasi, suction oropharyng, monitor gastro residual, memastikan tekanan cuff ETT 20-30 CmH2O (Başyiğit, 2017). Beberapa diantara bundle VAP yang merupakan intervensi mandiri perawat di ICU adalah tindakan oral hygiene pada pasien yang terpasang ventilator mekanik.

Penelitian mengungkapkan buruknya kesehatan mulut memiliki korelasi yang kuat dengan peningkatan kejadian VAP, terutama onset dini, pada 69 pasien $(42,6 \%)$ dengan kejadian VAP 117 episode per 1000 hari ventilator dimana kondisi kesehatan mulut yang sangat buruk memiliki 1,66 kali lipat (95\%CI: 1,001-2,75) peningkatan resiko VAP (Saensom et al., 2016). Penelitian yang dilakukan di Jepang mengungkapkan bahwa jumlah bakteri oral menurun secara signifikan setelah dilakukan prosedur oral hygiene (Muramatsu et al., 2018). Oleh karena itu intervensi ini menjadi tantangan tersendiri bagi perawat dalam melakukan oral hygiene pada pasien yang diintubasi.

Sebuah penelitian mengungkapkan tingkat kepatuhan perawat terhadap penerapan bundle VAP adalah sedang, dengan tingkat kepatuhan di seluruh rumah sakit adalah $56,32 \%$ yang relatif dapat diterima (Aloush, 2017; Masomeh \& Yazdannik, 2017).

Hal ini menunjukkan bahwa meskipun telah ada standar prosedur dari rumah sakit, tetapi kepatuhan dalam menerapkan strategi pencegahan khususnya oral hygiene masih dipengaruhi oleh beberapa faktor, sehingga review literatur ini penting dilakukan untuk mengidentifikasi beberapa faktor yang berpengaruh terhadap kepatuhan perawat dan solusinya dalam memberikan tindakan oral hygiene pada pasien di unit perawatan intensif.

\section{METODE PENELITIAN}

Metode penulisan ini adalah review literatur yang merupakan publikasi ilmiah dengan rentang waktu 5 tahun terakhir (2015-2020), pencarian dimulai dengan memasukkan kata kunci sesuai dengan topik review berdasarkan elemen PICO yaitu 
population, intervention, comparison, outcome pada 4 database, yaitu PubMed, Science Direct, wiley online lybrary dan google scholar. Setiap database menggunakan kata kunci antara lain dengan "Nurses AND Compliance OR Accordance AND Oral Hygiene OR bundle VAP AND Critical Care or Intensif Care Unit". Jumlah total artikel yang diidentifikasi adalah 19.773 artikel, kemudian dilakukan screening artikel dengan mengeluarkan artikel yang tidak berbahasa Inggris dan Indonesia, tidak full teks, publikasi 5 tahun terakhir, mengeluarkan artikel ganda dan sesuai dengan tujuan penelitian, sehingga didapatkan hasil 7 artikel yang memenuhi kriteria inklusi.

Kriteria inklusi sesuai dengan tujuan penelitian dalam review litertur ini adalah (1) artikel publikasi 5 tahun terakhir (2015-2020), (2) artikel tersedia full teks, (3) populasi adalah perawat di intensif care dewasa, dan (4) tujuan penelitian mengulas kepatuhan perawat terhadap penerapan bundle VAP/oral hygiene di unit perawatan intensif, sedangkan kriteria eksklusi adalah (1) artikel yang tidak sesuai dengan tujuan penelitian, (2) artikel duplikat dan (3) artikel yang tidak sesuai dengan hasil penelitian. Desain penelitian dalam review literatur ini adalah deskriptiv cross sectional, ramdomly eksperimental dan mix method.

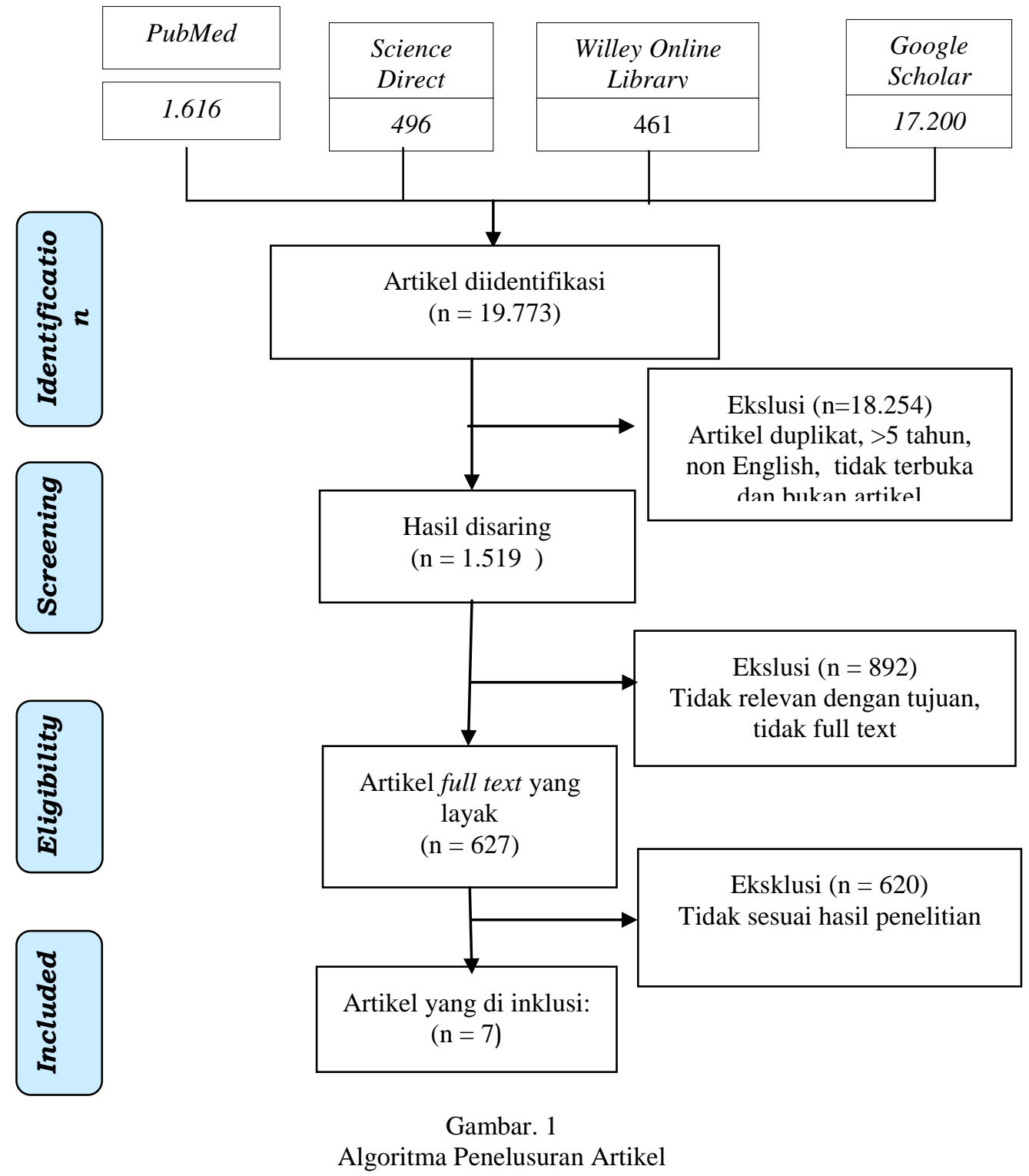


HASIL PENELITIAN

Tabel. 1

Sintesis Grid

\begin{tabular}{llcll}
\hline No & $\begin{array}{l}\text { Pengarang, Judul, } \\
\text { Jenis Literatur }\end{array}$ & $\begin{array}{c}\text { Tahu } \\
\mathrm{n}\end{array}$ & \multicolumn{1}{c}{ Tujuan } & \multicolumn{1}{c}{ Hasil Temuan } \\
\hline 1. & Tanguay et al., & 2019 & Mempelajari & Perilaku dan sikap yang \\
factors influencing & & faktor yang & dirasakan, mejadi penentu \\
oral care in intubated & & mempengaruhi & paling penting terhadap niat \\
intensive care & & perawat dalam & untuk terlibat dalam \\
patients, & & melakukan oral & perawatan mulut, \\
Deskriptif Korelation & & care pada pasien & pengetahun,SDM, \\
croos-sectional & & terintubasi & pengalaman kerja \\
& & dengan merujuk & merupakan faktor yang \\
& & pada TPB(teori & berpengaruh signifikan. \\
& & perilau & \\
& & Berencana). &
\end{tabular}

\begin{tabular}{|c|c|c|c|c|}
\hline 2. & $\begin{array}{l}\text { Alja'afreh et al., } \\
\text { Nurses' perception } \\
\text { and attitudes towards } \\
\text { oral care practices for } \\
\text { mechanically } \\
\text { ventilated patients, } \\
\text { Deskriptif cross- } \\
\text { sectional design }\end{array}$ & 2018 & $\begin{array}{l}\text { Mengetahui } \\
\text { sikap dan } \\
\text { persepsi perawat } \\
\text { ICU tentang } \\
\text { praktek } \\
\text { perawatan mulut } \\
\text { pada pasien } \\
\text { dengan ventilasi } \\
\text { mekanik }\end{array}$ & $\begin{array}{l}\text { Sebanyak } 76,8 \% \text { perawat } \\
\text { memberikan tanggapan, } \\
65 \% \text { perawat hanya } \\
\text { mengikuti protokol oral } \\
\text { care tertenu, } 68 \% \\
\text { menganggap sebagai tugas } \\
\text { tidak menyenangkan, } 29 \% \\
\text { menganggap tidak } \\
\text { mendapat pelatihan }\end{array}$ \\
\hline 3. & $\begin{array}{l}\text { Aloush, } \\
\text { Does educating } \\
\text { nurses with } \\
\text { ventilator-associated } \\
\text { pneumonia } \\
\text { prevention guidelines } \\
\text { improve their } \\
\text { compliance? } \\
\text { Randomly } \\
\text { eksperimental } \\
\text { Control } 2 \text { Group post } \\
\text { test Design }\end{array}$ & 2017 & $\begin{array}{l}\text { Membandingka } \\
\mathrm{n} \text { kepatuhan } \\
\text { perawat yang } \\
\text { menjalani } \\
\text { pendidikan } \\
\text { perawatan } \\
\text { intensif dan } \\
\text { yang tidak, serta } \\
\text { faktor lain yang } \\
\text { mempengaruhi } \\
\text { kepatuhan } \\
\text { perawat } \\
\text { terhadap bundle } \\
\text { VAP di } \\
\text { perawatan } \\
\text { intensif }\end{array}$ & $\begin{array}{l}\text { Skor rata-rata kepatuhan } \\
\text { adalah moderat, Untuk } \\
\text { kelompok eksperimen rata- } \\
\text { rata kepatuhan }=14,1 \pm 4,4, \\
\text { kelompok kontrol } 12,8 \pm \\
3,7, \text { dbandingkan dengan } \\
\text { kelompok kontrol, } \\
\text { experimen mendapat skor } \\
\text { lebih tinggi, namun secara } \\
\text { statistik tidak signifikan. }\end{array}$ \\
\hline 4. & $\begin{array}{l}\text { Aloush \& Al- } \\
\text { Rawajfa, } \\
\text { Prevention of } \\
\text { ventilator-associated } \\
\text { pneumonia in } \\
\text { intensive care units: } \\
\text { Barriers and } \\
\text { compliance, } \\
\text { Deskriptif cross- } \\
\text { sectional design }\end{array}$ & 2020 & $\begin{array}{l}\text { Mengevaluasi } \\
\text { kepatuhan } \\
\text { perawat jordania } \\
\text { dan hambatan } \\
\text { kepatuhan } \\
\text { terhadap } \\
\text { pencegahan } \\
\text { Ventilator } \\
\text { Associated } \\
\text { pneumonia } \\
\text { (VAP) }\end{array}$ & $\begin{array}{l}45,6 \% \text { melaporkan } \\
\text { kepatuhan tidak memadai, } \\
24,8 \% \text { memadai dan } 29,6 \% \\
\text { cukup, perawat dengan } \\
\text { pengalam lebih banyak } \\
\text { menunjukkan skor lebih } \\
\text { tinggi, minim pendidikan, } \\
\text { kebijakan protokol dan } \\
\text { sumber daya adalah } \\
\text { hambatan lain terhadap } \\
\text { kepatuhan. }\end{array}$ \\
\hline
\end{tabular}




\begin{tabular}{|c|c|c|c|c|}
\hline 5. & $\begin{array}{l}\text { Masomeh \& } \\
\text { Yazdannik, } \\
\text { Compliance with the } \\
\text { Standards for } \\
\text { Prevention of } \\
\text { Ventilator - } \\
\text { Associated } \\
\text { Pneumonia by Nurses } \\
\text { in the Intensive Care } \\
\text { Units, } \\
\text { Deskriptif cross- } \\
\text { sectional study }\end{array}$ & 2017 & $\begin{array}{l}\text { Melaukan } \\
\text { evaluasi } \\
\text { terhadap } \\
\text { kepatuhan } \\
\text { perawat dalam } \\
\text { melakukan } \\
\text { standar } \\
\text { pencegahan } \\
\text { VAP di unit } \\
\text { perawatan } \\
\text { intensif }\end{array}$ & $\begin{array}{l}\text { Kepatuhan perawat } \\
\text { terhadap standar } \\
\text { pencegahan adalah } 56,32 \% \text {, } \\
\text { namun keterbatasan waktu, } \\
\text { tenaga dan pengetahuan } \\
\text { perawat dinilai memiliki } \\
\text { pengaruh sehingga pihak } \\
\text { manajemen harus } \\
\text { menyediakan pelatihan dan } \\
\text { fasilitas guna meningkatkan } \\
\text { kualitas pelyanan pasien. }\end{array}$ \\
\hline 6. & $\begin{array}{l}\text { Andersson et al., } \\
\text { Intensive \& Critical } \\
\text { Care Nursing } \\
\text { Intensive care nurses } \\
\text { fail to translate } \\
\text { knowledge and skills } \\
\text { into practice - A } \\
\text { mixed-methods study } \\
\text { on perceptions of oral } \\
\text { care, } \\
\text { Mix method dengan } \\
\text { kuantitatif lebih } \\
\text { banyak dengan } \\
\text { melihat korelasi serta } \\
\text { analisis konten } \\
\text { kualitatif. }\end{array}$ & 2018 & $\begin{array}{l}\text { Mengidentifikas } \\
\text { i persepsi } \\
\text { perawat ICU, } \\
\text { mengenai oral } \\
\text { care sesuai } \\
\text { dengan } \\
\text { kerangka kerja } \\
\text { konseptual yang } \\
\text { berkontribusi } \\
\text { pada basis } \\
\text { pengetahuan. }\end{array}$ & $\begin{array}{l}\text { Perawat meganggap } \\
\text { perawatan mulut adalah } \\
\text { aspek penting dari pasien } \\
\text { yang diintubasi, perawat } \\
\text { dianggap kompeten } \\
\text { melaukan pengkajian dan } \\
\text { perawatan mulut tanpa } \\
\text { isntrumen, tetapi } \\
\text { berorientasi pada tugas } \\
\text { sehingga jarang di } \\
\text { dokumentasikan. }\end{array}$ \\
\hline 7. & $\begin{array}{l}\text { Saodah, } \\
\text { Knowledge of } \\
\text { Guideline VAP } \\
\text { Bundle Improves } \\
\text { Nurse Compliance } \\
\text { Levels in Preventing } \\
\text { Associated } \\
\text { Pneumonia (VAP) } \\
\text { Ventilation in the } \\
\text { Intensive Care Unit, } \\
\text { Cross-sectional }\end{array}$ & 2019 & $\begin{array}{l}\text { Menganalisa } \\
\text { pedoman terkait } \\
\text { hubungan } \\
\text { pengetahuan } \\
\text { tentang bundle } \\
\text { VAP dengan } \\
\text { kepatuhan } \\
\text { perawat } \\
\text { terhadap } \\
\text { pencegahan } \\
\text { VAP }\end{array}$ & $\begin{array}{l}\text { Terdapat hubungan yang } \\
\text { bermakna antara tingkat } \\
\text { pengetahuan dan } \\
\text { Kepatuhan perawat dalam } \\
\text { pelaksanaan bundle vap di } \\
\text { ruang ICU, p value } 0,022 \\
\text { ( }>0,05 \text { ), dengan nilai r }= \\
0,456 \text {, yang bermakna } \\
\text { hubungan yang kuat antara } \\
\text { pengetahuan dan kepatuhan } \\
\text { akan pencegahan terhadap } \\
\text { bundle VAP. }\end{array}$ \\
\hline
\end{tabular}

Berdasarkan hasil pencarian literatur didapatkan 7 artikel yang pada umumnya menilai pengetahuan, persepsi serta praktik, terhadap kepatuhan perawat dalam pelaksanaan bundle VAP termasuk oral hygiene pada pasien di unit perawatan intensif. Faktor yang berpengaruh terhadap kepatuhan perawat dalam pencegahan Ventilator Associated Pneumonia (VAP) diidentifikasi berdasarkan konten pengetahuan, persepsi dan praktik. Persepsi digambarkan sebagai tinggi atau rendah, dan didapatkan hasil bahwa perawat menganggap perawatan mulut pada pasien intubasi adalah hal yang penting, perawat dianggap kompeten dalam berbagai segi, melakukan assesmen perawatan mulut, walaupun tanpa instrumen, tetapi perawatan mulut yang dilakukan berorientasi sebagai tugas, dan tidak di dokumentasikan, sehingga perawat sulit mengartikan komponen ini kedalam praktik nya. 


\section{PEMBAHASAN}

Perawat sebagai pemberi layanan utama, memegang peranan yang sangat penting dalam menurunkan kejadian ventilator associated pneumonia, upaya untuk menurunkan kejadian VAP, seringkali mengalami hambatan yang akan berpengaruh pada kepatuhan perawat, pengetahuan dan pemahaman perawat berpengaruh pada tingkat kepatuhan perawat, perawat yang telah mendapat pelatihan tentang strategi pencegahan VAP diantaranya oral hygiene mengalami tingkat kepatuhan yang lebih tinggi dibanding yang tidak mendapat pelatihan sebelumnya (Aloush, 2017). Hal ini sejalan dengan penelitian yang dilakukan oleh Saodah (2019) yang mengatakan ada hubungan yang signifikan antara tingkat pengetahuan dan kepatuhan perawat dalam pelaksanaan bundle VAP, dengan $\mathrm{p}$ value $0,022(\mathrm{p}>0,05)$, dengan nilai $\mathrm{r}=0,456$. Hal ini menunjukkan bahwa semakin tinggi tingkat pendidikan seseorang, maka akan mempengaruhi tingkat pengetahuan dan pemahaman seseorang.

Pentingnya meningkatkan pengetahuan dan kompetensi perawat akan berpengaruh terhadap kepatuhan dalam menerapkan bundle VAP, hal ini diperkuat dengan penelitian lanjutan yang dilakukan oleh Aloush \& Al-Rawajfa (2020) yang mengatakan, bahwa selain pengetahuan, faktor pengalaman kerja dari perawat juga akan mempengaruhi kepatuhan, sebanyak 45,6\% melaporkan kepatuhan kurang, 24,8\% memadai, dan 29,6\% cukup, sehingga fokus program pelatihan dan pendidikan untuk perawat lulusan baru menjadi target dalam RS tersebut, hal ini membuktikan bahwa kebijakan protokol dan sumber daya adalah faktor hambatan lain dalam kepatuhan..

\section{Pengetahuan dan Pemahaman Perawat terhadap Kepatuhan dalam Pelaksanaan Bundle VAP:}

Penelitian yang dilakukan oleh Aloush (2017) yang membandingkan dua kelompok perawat dari lima rumah sakit yang berbeda di Yordania, dengan rasio perbandingan perawat dan pasien 1:1 sampai 1:2, dengan jumlah peserta 59 pada kelompok eksperimen, dan 43 pada kelompok kontrol termasuk peserta yang drop out. Kelompok eksperimen telah menerima pelatihan tentang pedoman pencegahan VAP, sedangakan pada kelompok kontrol tidak diberikan pelatihan apapun, penilaian dilakukan selama 6 bulan dengan sitsem blind, didapatkan pada kelompok eksperimen rata-rata kepatuhan $14,1 \pm 4,4$, dan kelompok kontrol 12,8 $\pm 3,7$, walaupun tidak signifikan secara statistik, skor kepatuhan secara keseluruhan adalah moderat, dimana kelompok eksperimen mendapat skor lebih tinggi dibanding kelompok kontrol, hal ini membuktikan bahwa pengetahuan memiliki hubungan terhadap tingkat kepatuhan, meskipun demikian faktor perancu lain yang signifikan ditemukan adalah beban kerja perawat.

Penelitian lanjutan yang dilakukan oleh Aloush \& Al-Rawajfa (2020) mengevaluasi kepatuhan perawat dalam mencegah VAP, faktor yang berpengaruh, serta hambatan yang dialami perawat, penelitian dengan design deskriptif cross sectional merekrut sampel dari 294 perawat ICU dari sembilan rumah sakit, dengan rasio total perawat dan pasien adalah 1:2, dengan jumlah total 7 perawat per sift, untuk skor kepatuhan perawat berdasarkan kuesioner skala likert, dimana uji t indevenden dan ANOVA menunjukkan bahwa perawat yang telah mendapatkan pelatihan sebelumnya mengenai manjemen VAP, dan memiliki banyak pengalaman kerja, menunjukkan skor yang lebih tinggi, kepatuhan hand hygiene sebelum suction $(\mathrm{x} 2=17,38, \mathrm{p}=0,01)$, juga ada hubungan yang signifikan terhadap bundle penyapihan ventilator secara dini $(\mathrm{x} 2=11,31, \mathrm{p}=0,001)$, begitupula perawat yang memiliki pengalaman dengan pengaturan posisi pasien 
menunjukkan hasil yang signifikan $(\mathrm{x} 2=12,55, \mathrm{p}<0,001)$, dan untuk perawatan mulut, menunjukkan nilai yang signifikan $(\mathrm{x} 2=8,27, \mathrm{p}<0,001)$.

Hal ini menunjukkan bahwa dengan pengalaman kerja yang lebih banyak akan mempengaruhi pengetahuan seseorang. Dari hasil penelitian ini 56\% setuju bahwa pendidikan yang kurang akan menjadi penghalang kepatuhan, dan $21 \%$ mengatakan kurangnya kebijakan dan protokol di rumah sakit mereka sebagai hambatan utama. Sekitar 23\% sangat tidak setuju jika kurangnya keterampilan dianggap sebagai penghambat.

Penelitian yang dilakukan oleh Saodah (2019) sebuah penelitian yang dilakukan di Indonesia, dengan melibatkan 25 responden yang merupakan perawat ICU dan telah mengikuti inhouse training bundle VAP, tingkat pengetahuan responden di ukur dengan kuesioner pengetahuan dengan 20 pertanyaan, telah dilakukan uji validitas dan reliabilitas dengan nilai 0,803 , dan cronbach alpha 0,784 , hasil penelitian menujukkan sebanyak 52\% memiliki tingkat pengetahuan baik, penelitian ini juga menunjukkan ada korelasi antara tingkat pengetahuan dengan kepatuhan perawat dalam penerapan bundle $V A P$ untuk menurunkan kejadian VAP, meskipun demikian sebanyak 36\% masih ada yang tidak patuh, sehingga diharapkan perawat dapat meningkatkan pengetahuan dan kompetensinya yang akan mempengaruhi kepatuhannya dalam menerapkan bundle VAP.

\section{Persepsi dan Sikap Perawat sebagai Pengaruh terhadap Kepatuhan Melaksanakan Bundle VAP}

Penelitian menurut Alja'afreh et al., (2018) sebanyak 96 perawat ICU dari tiga rumah sakit di Yordania bersedia dianalisis mengenai persepsi dan sikapnya terhadap perawatan mulut untuk pencegahan VAP , 53,1\% adalah perempuan, 78,9\% dengan gelar sarjana, lebih dari 50\% berasal dari ICU bedah, hasil penilaian persepsi tentang perawatan mulut hanya $65 \%$ yang menerapkan perawatan mulut tertentu, $46 \%$ memberi jawaban yang tepat untuk frekuensi suction, 63\% menggunakan sikat gigi, untuk skor sikap yaitu sebanyak $82 \%$ perawat setuju jika perawatan mulut adalah prioritas tinggi, dan 15\% kurang setuju, untuk skor sikap negatif $68 \%$ menganggap tindakan membersihkan rongga mulut tidak menyenangkan dan sulit dilakukan, setengah dari peserta $(47 \%)$ mengatakan apapun yang mereka lakukan, kondisi mulut pasien yang berventilasi mekanik sebagian besar akan memburuk, walaupun persepsi dan sikap perawat ini bukan jaminan terhadap kepatuhan, namun hal ini dapat menjadi perhatian khusus dari pihak rumah sakit untuk memberikan pelatihan tentang pedoman perawatan mulut. Sehingga dalam penelitian ini walaupun $71 \%$ telah diberikan pelatihan untuk melakukan perawatan mulut, namun $78 \%$ menyatakan ingin mempelajari lebih lanjut mengenai metode terbaik dengan menghadiri lokakarya dan pendidikan berkelanjutan.

Penelitian yang dilakukan di Swedia oleh Andersson et al., (2018) mengenai persepsi perawat ICU tentang pentingnya perawatan mulut, penelitian ini adalah mix method dengan lebih dominan sebagai kuantitatif, sebanyak 88 dari 217 perawat di enam unit perawatan intensif terdaftar, dengan tingkat respon yang beragam dari $32 \%$ 75\%. Dari hasil analisa data kuantitatif, persepsi digambarkan sebagai tinggi atau rendah, dan didapatkan hasil bahwa perawat menganggap perawatan mulut pada pasien intubasi adalah hal yang penting, perawat dianggap kompeten dalam berbagai segi, melakukan assesmen perawatan mulut, walaupun tanpa instrumen, tetapi perawatan mulut yang dilakukan berorientasi sebagai tugas, dan tidak di dokumentasikan, sehingga perawat sulit mengartikan komponen ini kedalam praktik nya. 
Penelitian yang dilakukan oleh Tanguay et al., (2018) di Canada terhadap seluruh perawat ICU di Provinsi Quebec, sebanyak 38,5\% (375) perawat telah berpartisipasi, walaupun tingkat respon terbilang rendah, penelitian melihat faktor yang mempengaruhi perawatan mulut yang diberikan pada pasien yang diintubasi menggunakan teori perilaku terencana (Theory of Planned Behavior), beradasarkan karakteristik 90\% adalah wanita, $33 \%$ memilki pengalaman bekerja di ICU, walaupun hanya 1-5 tahun, $87 \%$ dari mereka telah menunjukkan kepatuhan dalam melaukan oral hygiene, hal ini membuktikan ada hubungan yang kuat antara kontrol keyakinan dan perilaku, meskipun lemah $(r=0,44)$, namun antara sikap dan niat terdapat korelasi yang signifikan $(r=0,30$; $\mathrm{p}<0,001)$, oleh karena itu perawat yang memiliki skor sikap yang tinggi, akan mendapat nilai besar untuk mengadopsi perilaku tersebut, sehingga disimpulkan bahwa sikap dan niat merupakan faktor yang berpengaruh terhadap kepatuhan perawat dalam bekerja secara profesional.

\section{Praktik/Pelayanan sebagai Pendukung Kepatuhan terhadap Bundle VAP}

Penelitian yang dilakukan oleh Masomeh \& Yazdannik (2017) sebanyak 120 perawat di 11 unit ICU dari empat rumah sakit dilakukan pengamatan terhadap kepatuhan dalam melaksanakan bundle VAP selama 4 bulan, dengan metode observasi dan daftar penilaian mengenai kinerja perawat dan struktur fisik ICU. 85,8\% adalah perempuan, 85,8\% dari perawat memiliki pengalaman kerja kurang dari 10 tahun, hasil penelitian menunjukkan tingkat kepatuhan 56,32\% dengan presentasi kepatuhan berbeda diantara empat rumah sakit, RS A 55,70\%, RS B 49,31\%, RS C 65\% dan D $63,81 \%$. Diantara kepatuhan dalam bundle VAP, ada beberapa yang dapat diterima, tetapi ada juga yang tidak signifikan yaitu mengenai konsistensi dalam pelaksanaan hand hygiene sebelum dan setelah kontak dengan pasien, oral hygiene di setiap shift, suction sebelum reposisi pasien dan persiapan untuk penyapihan dari ventilator. Sistem pemantauan, evaluasi dan pelaporan tidak ditemukan pada rumah sakit yang disurvey, hal ini berpengaruh pada tingkat kepatuhan perawat, sehingga perhatian serius dari manajemen rumah sakit masih sangat diperlukan.

Penelitian yang dilakukan oleh Saodah (2019) sebuah penelitian yang dilakukan di Indonesia, dengan melibatkan 25 responden yang merupakan perawat ICU dan telah mengikuti inhouse training bundle VAP, tingkat pengetahuan responden di ukur dengan kuesioner pengetahuan dengan 20 pertanyaan, telah dilakukan uji validitas dan reliabilitas dengan nilai 0,803 , dan cronbach alpha 0,784 , hasil penelitian menujukkan sebanyak 52\% memiliki tingkat pengetahuan baik

\section{Persepsi dan Sikap Perawat Merupakan Pengaruh dalam Kepatuhan Pelaksanaan Bundle VAP}

Sesuai dengan penelitian yang dilakukan oleh Andersson et al., (2018) dari hasil identifikasi persepsi perawat ICU mengenai pencegahan VAP dari aspek perawatan mulut, sebagian besar menganggap hal ini adalah prioritas untuk pasien yang diintubasi, namun walaupun sebagian menganggap hal ini adalah tugas rutin, sehingga tidak terfokus pada peningkatan kualitas pelayanan pasien, hal ini sejalan dengan penelitian yang dilakukan oleh Alja'afreh et al., (2018) yang menemukan bahwa persepsi perawat ICU mengenai oral care $82 \%$ menganggap sebagai prioritas, meskipun demikian $68 \%$ menganggap sebagai hal yang tidak menyenangkan, dan sulit dilakukan, $29 \%$ mengatakan tidak pernah mendapat pelatihan, hal ini disimpulkan bahwa sikap perawat masih termasuk kategori rendah, sehingga diperlukan pelatihan mengenai protokol 
perawatan mulut, untuk meningkatkan sikap dan persepi perawat yang akan mempengaruhi tingkat kepatuhannya dalam menurunkan kejadian VAP.

Berbeda dengan temuan mengenai sikap dan niat mempengaruhi kepatuhan perawat dalam menerapkan bundle VAP, penelitian ini merujuk pada teori perilaku terencana yang dilakukan untuk meningkatkan pemahaman perawat terhadap praktek perawatan mulut, hal ini menekankan perlunya keterlibatan interpofesional dalam memprioritaskan oral care sebagai bagian penting dalam bundle VAP (Tanguay, et al, 2019). Hal ini sejalan dengan penelitian yang dilakukan oleh Harmon \& Grech (2020) dengan metode kualitatif etnografi, menyatakan bahwa pengetahuan dan partisipasi masih kurang dari interprofesional, kemungkinan disebabkan karena kurang tersedianya fasilitas dan peralatan, serta sistem pendokumentasian yang tidak mendukung.

Pelaksanaan praktek/pelayanan pasien sebagai pendukung kepatuhan perawat, sesuai dengan penelitian oleh yang menyatakan bahwa pelaksanaan pencegahan bundle VAP, tidak terlepas dari tersedianya fasiltas yang memadai, pedoman protokol dari rumah sakit yang akan menjadi pedoman bagi perawat dalam melakasanakan bundle VAP, seperti yang dilaporkan dalam penelitian Masomeh \& Yazdannik (2017) bahwa RS B memiliki tingkat kepatuhan kurang dibanding tiga RS lainnya yang disurvey yaitu 49,31\%, disebabkan karena tidak adanya evaluasi pemantauan, protokol dalam pelaksanaan standar pencegahan di rumah sakit.

\section{SIMPULAN}

Study literatur ini menunjukkan bahwa dalam menerapkan intervensi bundle VAP khususnya oral hygiene terdapat beberapa faktor yang akan mempengaruhi kepatuhan perawat, diantaranya pengetahuan/pemahaman perawat, persepsi dan sikap serta pelayanan/praktek dalam pelaksanaannya, meskipun demikian keterbatasan waktu, motivasi, beban kerja perawat, tidak tersedianya prosedur oral hygiene dan kurangnya kolaborasi interprofesional, adalah faktor yang turut memegang peranan penting, sehingga solusi terbaik untuk meningkatkan kepatuhan perawat adalah meningkatkan pengetahuan dan kompetensi perawat, peran serta pihak rumah sakit sebagai penyedia fasilitas, dan tidak terlepas dari dukungan profesi lain untuk bersama-sama dalam menerapkan bundle VAP, sehingga insiden VAP dapat dicegah.

\section{SARAN}

Diharapkan tinjauan literatur ini dapat menambah khasanah ilmu pengetahuan bagi perawat keperawatan kritis dan pihak manajemen rumah sakit untuk mengetahui faktor yang berpengaruh terhadap kepatuhan perawat terhadap pencegahan infeksi nosokimoal, tinjauan literatur ini dapat dijadikan referensi bagi perawat untuk melakukan penelitian selanjutnya terkait variabel yang mendukung tingkat keselamatan pasien utamanya di unit perawatan intensif.

\section{DAFTAR PUSTAKA}

Alja'afreh, M. A., Mosleh, S. M., \& Habashneh, S. S. (2018). Nurses' Perception and Attitudes Towards Oral Care Practices for Mechanically Ventilated Patients. $\begin{array}{llll}\text { Saudi Medical 39(4), } & \text { 379-385. }\end{array}$ https://doi.org/10.15537/smj.2018.4.21749

Aloush, S. M. (2017). Does Educating Nurses with Ventilator-Associated Pneumonia Prevention Guidelines Improve Their Compliance? American Journal of Infection Control, 45(9), 969-973. https://doi.org/10.1016/j.ajic.2017.04.009 
Aloush, S. M., \& Al-Rawajfa, O. M. (2020). Prevention of Ventilator-Associated Pneumonia in Intensive Care Units: Barriers and Compliance. International Journal of Nursing Practice, March, 1-7. https://doi.org/10.1111/ijn.12838

Andersson, M., Wilde-larsson, B., \& Persenius, M. (2018). Intensive \& Critical Care Nursing Intensive Care Nurses Fail to Translate Knowledge and Skills Into Practice - A Mixed-Methods Study on Perceptions of Oral Care. Intensive \& Critical Care Nursing. https://doi.org/10.1016/j.iccn.2018.09.006

Bassi, G. L., Senussi, T., \& Xiol, E. A. (2017). Prevention of Ventilator-Associated Pneumonia. Current Opinion in Infectious Diseases, 30(2), 214-220. https://doi.org/10.1097/QCO.0000000000000358

Başyiğit, S. (2017). Clinical Pulmonary Infection Score (CPIS) as a Screening Tool in Ventilatory Associated Pneumonia (VAP). SiSli Etfal Hastanesi Tip Bulteni / The Medical Bulletin of Sisli Hospital, 2, 133-141. https://doi.org/10.5350/semb.20170208030528

Harmon, J., \& Grech, C. (2020). Technical and Contextual Barriers to Oral Care: New Insights from Intensive Care Unit Nurses and Health Care Professionals. Australian Critical Care, 33(1), 62-64. https://doi.org/10.1016/j.aucc.2019.06.001

International Nosocomial Infection Control Consortium,Rosenthal, V. D. (2016). International Nosocomial Infection Control Consortium (INICC) resources: INICC multidimensional approach and INICC surveillance online system. American Journal of Infection Control, 44(6), e81-e90. https://doi.org/10.1016/j.ajic.2016.01.005

Kalil, A. C., Metersky, M. L., Klompas, M., Muscedere, J., Sweeney, D. A., Palmer, L. B., Napolitano, L. M., \& Grady, N. P. O. (2016). Management of Adults with Hospital-Acquired and Ventilator-Associated Pneumonia : 2016 Clinical Practice Guidelines by the Infectious Diseases Society of America and the American Thoracic Society. 63, 61-111. https://doi.org/10.1093/cid/ciw353

Khan, H. A., Baig, F. K., \& Mehboob, R. (2017). Nosocomial Infections: Epidemiology, Prevention, Control and Surveillance. Asian Pacific Journal of Tropical Biomedicine. https://doi.org/10.1016/j.apjtb.2017.01.019

Masomeh, S., \& Yazdannik, A. (2017). Compliance with the Standards for Prevention of Ventilator - Associated Pneumonia by Nurses in the Intensive Care Units. Iranian Journal of Nursing and Midwifery Research, 22((1)), 31-36. https://doi.org/10.4103/1735-9066.202073

Muramatsu, K., Matsuo, K., Kawai, Y., Yamamoto, T., Hara, Y., Shimomura, Y., Yamashita, C., \& Nishida, O. (2018). Comparison of Wiping and Rinsing Techniques after Oral Care Procedures in Critically Ill Patients during Endotracheal Intubation and After Extubation: A Prospective Cross-Over Trial. Japan Journal ofNursing Science. https://doi.org/10.1111/jjns.12217

Saddki, N., Elani, F., Sani, M., \& Tin-oo, M. M. (2014). Oral Care for Intubated Patients: A Survey of Intensive Care Unit Nurses. 1-10. https://doi.org/10.1111/nicc.12119

Saensom, D., Merchant, A. T., Ruaisungnoen, W., \& Pitiphat, W. (2016). Oral Health and Ventilator-Associated Pneumonia among Critically ill Patients: A Prospective Study. June, 709-714. https://doi.org/10.1111/odi.12535 
Saodah, S. (2019). Knowledge of Guideline VAP Bundle Improves Nurse Compliance Levels in Preventing Associated Pneumonia (VAP) Ventilation in the Intensive Care Unit. Media Keperawatan Indonesia, 2(3), 113. https://doi.org/10.26714/mki.2.3.2019.113-120

Tanguay, A., LeMay, S., Reeves, I., Gosselin, É., \& St-Cyr-Tribble, D. (2019). Factors Influencing Oral Care in Intubated Intensive Care Patients. Nursing in Critical Care, May, 1-8. https://doi.org/10.1111/nicc.12456 